\title{
Effect of Different Drying Methods on the Quality Characteristics of Pangasius hypophthalmus
}

\author{
Gonugodugu Praveen Kumar ${ }^{1}$, K.A. Martin Xavier ${ }^{1}$, Binaya Bhusan Nayak ${ }^{1}$, \\ H. Sanath Kumar ${ }^{1}$, Gudipati Venkateshwarlu' ${ }^{2}$ and Amjad K. Balange ${ }^{1^{*}}$ \\ ${ }^{1}$ Department of Post-Harvest Technology, ICAR-Central Institute of Fisheries Education, \\ Versova, Mumbai-400061, Maharashtra, India \\ ${ }^{2}$ Education Division, Indian Council of Agricultural Research, New Delhi -1100001, India \\ *Corresponding author
}

\begin{tabular}{|c|c|}
\hline & A B S T R A C T \\
\hline Koywords & \multirow{6}{*}{$\begin{array}{l}\text { The objective of the present study was to investigate the effect of sun drying, salt drying } \\
\text { and kiln drying }\left(50^{\circ} \mathrm{C}, 60^{\circ} \mathrm{C}, 70^{\circ} \mathrm{C}\right) \text { on the quality of Pangasius. The changes in proximate } \\
\text { composition, physico chemical, microbiological and sensory evaluation were analyzed. } \\
\text { From the results, it was observed that salt dried Pangasius had the lowest } \mathrm{pH}(5.01) \text {. } \\
\text { Highest TVBN values were recorded in unsalted sundried Pangasius }(29.28 \mathrm{mgN} / 100 \mathrm{~g}) \text {. } \\
\text { Pangasius mechanically dried at } 70{ }^{\circ} \mathrm{C} \text { had the lowest peroxide value (PV) }(2.50 \mathrm{meq} \text { of } \\
\mathrm{O}_{2} / \mathrm{kg} \text { of fat) and the highest was recorded in salted sundried Pangasius }\left(4.53 \mathrm{meq} \mathrm{of} \mathrm{O}_{2} / \mathrm{kg}\right. \\
\text { of fat). The total viable count (TVC) was higher in sun dried Pangasius }(5.02 \mathrm{log} \mathrm{cfu} / \mathrm{g}) \\
\text { and the lowest TVC was observed in mechanically dried Pangasius at } 70{ }^{\circ} \mathrm{C}(2.53 \mathrm{log} \\
\text { cfu/g). Based on the sensory scores, salt and mechanically dried Pangasius had superior } \\
\text { quality whereas sun dried Pangasius was inferior in quality. Salt drying can be the most } \\
\text { suitable and cost effective method for preserving the marketable size Pangasius. }\end{array}$} \\
\hline & \\
\hline & \\
\hline Pangasius, Quality. & \\
\hline Article Info & \\
\hline $\begin{array}{l}\text { Accepted: } \\
\text { 04 September } 2017 \\
\text { Available Online: } \\
10 \text { October } 2017\end{array}$ & \\
\hline
\end{tabular}

\section{Introduction}

Fish is an important source of animal protein due to its high nutritional value, good quality proteins containing most of the essential amino acids and important minerals such as phosphorus, calcium, magnesium etc. (Chukwu, 2009; Jain and Pathare, 2007; Sarower-E-Mahfuj et al., 2012) Fish is one of the most perishable foods because of its suitable medium for spoilage after harvest. High ambient temperature prevalent in tropics is responsible for faster spoilage and deterioration of tropical species. Hence quick preservation of fish is important which includes traditional methods like salting or brining, sun drying, solar drying, air drying and smoking in smoking kilns (Mustapha et al., 2014).

In India, most of the fishermen in villages use curing as a method of preservation. Among curing methods, fishermen use drying, salt curing, smoking or fermentation for the preservation of fish. Dried aquatic products are popular as one of the delicious and convenient food items (Rahman, 2006). Drying is one of the oldest methods of preservation of fish which improves the stability of fish by reducing the water and 
microbial activity, minimizing physical and chemical changes during storage (Darvishi et al., 2012) and brings a substantial reduction in weight and volume, minimizing packaging, storage and transportation costs (Vega-Gálvez et al., 2009). Traditionally sun drying of fish was carried out under the open sun, a low-cost preservation technique used from days immemorial to preserve the fish (Jain and Pathare, 2007). The limitation to control weather conditions, drying process and parameter, high labor cost, insect infestation, the requirement of large drying area, mixing with dust and other foreign particles (Jain and Pathare, 2007) long processing time and poor hygiene of product have led to the development of kiln dryers or solar dryers. Hot air drying employs convection system with controlled air velocity and humidity, high temperatures but involves high energy consumption, bacterial contamination and possible quality change (Selmi et al., 2010). Traditionally, fish products were immersed in concentrated solutions containing salt or other curing agents that can impregnate into the muscle (Valencia-Pérez et al., 2008) and used as a pre-treatment before drying to achieve good quality product (Taiwo et al., 2003). Salting as a pre-treatment enhances the capability of drying in reducing the water activity of the product within shorter time allowing microbial quality preservation and changing the sensorial quality of food (Chabbouh et al., 2011).

The quality of sardine dried with fish rack, solar drier and traditional sun drying was evaluated and observed that fish rack assisted sundried and solar dried sardines to have better quality than sun dried sardines (Immaculate et al., 2012). The influence of temperature, air velocity and thickness of tilapia fillets on moisture ratio and drying rate was studied and it was observed that drying took place only in falling rate period. Moisture ratio decreased and drying rate increased with increase in drying temperature, drying velocity and decrease of fillet thickness (Guan et al., 2013). The effect of drying methods (smoking kiln at $70-85^{\circ} \mathrm{C}$ and electric oven at $120^{\circ} \mathrm{C}$ ) on nutritional properties of tilapia fish was evaluated and found that electric oven will improve protein quality in tilapia (Chukwu, 2009). The effects of drying conditions on drying kinetics at different temperatures $\left(35,40\right.$ and $\left.50^{\circ} \mathrm{C}\right)$ and air velocities $(0.5,1.5$ and $2 \mathrm{~m} / \mathrm{s})$ of lightly salted sardine were investigated and two falling rates were observed (Bellagha et al., 2002).

Pangasius has become as one of the candidate species for aquaculture in India due to its high production rate. However, utilization of Pangaius in fresh form has got limitation and there is an urgent need to find out alternative ways of processing in the form of low-cost processing and curing is one of such method. The objective of the present study is to investigate the effect of different drying process on the quality of dried product produced from Pangasius. In this study, Pangasius was dried at 50, 60 and $70^{\circ} \mathrm{C}$ in kiln dryer along with the traditional sun drying and salt drying. The present investigation provides information on the changes that occur in these different drying conditions on the quality of marketable size Pangasius.

\section{Materials and Methods}

\section{Raw material and processing}

Fish was purchased from the fish market in Dadar, Mumbai, India, iced immediately and brought to the laboratory within 1 hour. The length and weight of Pangasius varied between 36-43 cm and 800-1100 grams respectively. Upon arrival to the laboratory, the fish were washed with chilled water to remove dirt and slime and were beheaded, 
eviscerated and thereafter split open from the ventral side in butterfly style. Again the fish were washed thoroughly with chilled water to remove adhering blood and viscera. The butterfly style cut fish were used for drying. For salt drying, fishes were dry salted at $1: 1$ ratio (fish: salt) at room temperature $\left(32^{\circ} \mathrm{C}\right)$ for 48 hours before drying. After 48 hours the fishes were taken out and excessive salt on the surface was rubbed off and was sundried.

\section{Drying experiments}

For sun drying, the fishes were dried under sunlight by hanging the fishes by using hooks to rope with the tail side up and for kiln drying the fishes were hanged with head side up. The average temperature for sun drying varied from $30^{\circ} \mathrm{C}(9 \mathrm{AM})$ to $42^{\circ} \mathrm{C}(12 \mathrm{PM})$. The kiln drying was carried out in the Accelerated mechanical dryer (Yarrow \& Co Ltd, Glasgow, Scotland) at controlled temperatures of 50,60 and $70^{\circ} \mathrm{C} \pm 5^{\circ} \mathrm{C}$ with an air velocity of $2.0 \pm 0.3 \mathrm{~m} / \mathrm{s}$ maintained in each test.

The sampling was carried out by taking 4 fish (3 for biochemical and microbial analysis and 1 for sensory evaluation) and the muscle portion of all fishes was ground to fine powder, mixed, weighed, macerated in pestle and motor and was used for analyses.

\section{Proximate composition}

Moisture, fat, protein and ash content were determined according to AOAC 2000. Differences in weight were recorded after drying the sample in hot air oven at $100 \pm 5^{\circ} \mathrm{C}$ overnight to determine the moisture content. The crude protein content was measured by using the micro-Kjeldahl method using Kelplus equipment (Pelican instruments, Chennai, India). Ashing was done by incineration of the sample in a muffle furnace (CEM Corporation, USA) at $550 \pm 50{ }^{\circ} \mathrm{C}$ until white ash was obtained.
Total lipid was estimated by Soxhlet extraction method with diethyl ether as solvent.

\section{Biochemical quality parameters}

Ten grams of fish was homogenized in $50 \mathrm{~mL}$ distilled water in a homogenizer (Polytron system PT 2100, Kinematica, AG, Germany) for 30 seconds and the $\mathrm{pH}$ was measured using the digital $\mathrm{pH}$ meter (Eutech tutor $\mathrm{pH} /$ C meter, Eutech Instruments, Singapore). TVB-N was determined based on the method described by Vyncke (1996) using TCA with slight modifications. Peroxide value (PV) was expressed as meq of $\mathrm{O}_{2} / \mathrm{kg}$ of fat and determined according to the method of Jacobs (1958) and the content of free fatty acids (FFA) was determined from the chloroform extracts of muscles ground with anhydrous sodium sulphate according to AOAC, 2000. Thiobarbituric acid reactive substances (TBARS) were estimated by the method of Tarladgis et al., (1960).

\section{Microbiological quality parameters}

The microbiological parameters such as Total Viable Count (TVC) and Escherichia coli were carried out as per APHA (2001). 10 grams of the sample was aseptically weighed and transferred to a sterile stomacher bag and $90 \mathrm{ml}$ of sterile physiological saline $(\mathrm{NaCl}$ $0.85 \% \mathrm{w} / \mathrm{v}$ ) was added and the mixture was homogenized using stomacher (Lab Blender 400, Seward Medical, UK). For the enumeration of total plate count, $0.1 \mathrm{ml}$ of the serial dilution of homogenate was spread on Plate count agar (Himedia, India) and incubated at $37^{\circ} \mathrm{C}$ for 2 days. Enumeration of Escherichia coli was done by MPN method with initial inoculation of the sample at different volumes by 3-tube method in Lauryl tryptose broth (Lauryl sulphate broth) (Himedia, India) for coliforms for 24 hours and then positive tubes were re-inoculated in EC broth with 24 hours incubation at $37{ }^{\circ} \mathrm{C}$. 


\section{Sensory evaluation}

The sensory evaluation for overall acceptability was carried out after cooking the selected fish and it was done by 10 trained panellists using 9 point hedonic scales viz., Like extremely (9), Like very much (8), Like moderately (7), Like slightly (6), Neither like nor dislike (5), Dislike slightly (4), Dislike moderately (3), Dislike very much (2), Dislike extremely (1).

\section{Statistical analysis}

All analyses were carried out in triplicates and subjected to tests. Analysis of variance was performed by one-way ANOVA procedures with the application of Duncan's multiple range tests and descriptive statistics using SPSS 16 (SPSS, 2010). The least significant difference (LSD) was used to test for difference between means and significance was defined at $\mathrm{P}<0.05$. Results are reported as mean values of determinations \pm Standard Deviation.

\section{Results and Discussion}

Higher moisture content will make the product susceptible to microbial and enzymatic spoilage. Pangasius having a moisture content of $78 \%$ is susceptible to spoilage if it is not preserved properly. Though modern preservation techniques are available, they are costly for farmers and fishermen. So curing of fish, which is a lowcost preservation technique and easily adaptable can be used as a method of preservation of Pangasius. Higher temperature will lead to faster drying rate and shorter drying time (Guan et al., 2013).

\section{Changes in proximate composition}

The fresh Pangasius consisted of moisture $79.32 \pm 0.87 \%$, protein $16.96 \pm 0.31 \%$, fat
$2.02 \pm 0.06 \%$ and ash $1.44 \pm 0.18 \%$. The moisture content has decreased during mechanical drying of Pangasius from 78.14\% (fresh) to $16.67,13.50$ and $14.53 \%$ at temperatures 50, 60 and $70{ }^{\circ} \mathrm{C}$ respectively (Table 1). During sun drying of salted and unsalted Pangasius, a decrease in moisture was observed with values of $15.36 \%$ and $14.59 \%$ respectively. The decrease in moisture content may be due to the loss of free water present in muscle due to ingress of heat and salt. During drying, the water activity will decrease but the fat, protein and carbohydrate contents increase with water loss, $\mathrm{pH}$ changes, increase in free amino acids and fatty acids was reported (Collignan et al., 2008). Moisture content decreased in kiln dried and electric oven dried tilapia from $70.15 \%$ to 20.12 and $17.13 \%$ respectively (Chukwu, 2009). Immaculate et al., (2012) reported a decrease in moisture from 11.60, 8.31 and $4.0 \%$ in sun dried, rack dried and solar dried sardine.

The protein content increased during mechanical drying of Pangasius from 18.23\% (fresh) to 62.77, 65.16 and $63.98 \%$ at temperatures of 50,60 and $70{ }^{\circ} \mathrm{C}$ respectively (Table 2). The protein content of salted and unsalted sundried Pangasius was reported to be $55.53 \%$ and $63.39 \%$ respectively. An increase in protein content was due to aggregation of proteins after the removal of water molecules present between proteins during drying (Ninawe and Ratnakumar, 2008). The increase in drying time and loss of moisture leads to denaturation of the protein (Begum et al., 2013). Protein was not lost during kiln and electric oven drying of cat fish (Clarias gariepinus) (Chukwu and Shaba, 2009). Protein content has increased in sardine during rack drying, solar drying and traditional drying (Immaculate et al., 2012). Protein content increased from $23.06 \%$ to 63.64 and $64.10 \%$ in kiln dried and electric oven dried Tilapia (Chukwu, 2009). 
The crude fat of Pangasius has increased from $2.29 \%$ (fresh) to $15.45,15.31$ and $14.48 \%$ during mechanical drying at temperatures of 50, 60 and $70{ }^{\circ} \mathrm{C}$ respectively (Table 1). An increase in fat content was also observed in salted and unsalted Pangasius during sun drying with values of $9.32 \%$ and $15.17 \%$ respectively. The fat content increases with a decrease in water content as the lipid plus water content of fish flesh equal to $80 \%$ (Bligh et al., 1988). According to Chukwu and Saha (2009) fat may exude with moisture evaporation and extended heat treatment may lead to the removal of lipids in smoking kiln than in electric oven. An increase in fat was observed from $12.85 \%$ to $28.03 \%$ and $20.25 \%$ respectively in kiln dried and electric oven dried tilapia (Chukwu, 2009).

The ash content has increased from $1.44 \%$ (fresh) to 3.63, 4.38 and $4.88 \%$ during mechanical drying of Pangasius at temperatures of 50,60 and $70{ }^{\circ} \mathrm{C}$ respectively (Table 1). Ash content of salted and unsalted sundried Pangasius was recorded as $18.72 \%$ and $5.22 \%$ respectively. The highest ash content was observed in the salt dried Pangasius (18.72\%) which may be due to the penetration of salt followed by unsalted sun dried Pangasius due to the accumulation of dust or other foreign bodies. During incineration, organic matter is removed and inorganic material will remain as ash (Clucas and Ward, 1996). Sun drying in open space allows the settling of wind-borne dust, insect and bird infestation and increases inorganic content may be a probable reason for the increase in ash content (Immaculate et al., 2012). The higher ash content was due to the substantial loss of moisture (Mustapha et al., 2014). An increase in ash content was observed in kiln dried and electric oven dried catfish (Clarias gariepinus) from $3.06 \%$ to $3.92 \%$ and 3.62\% (Chukwu and Saha, 2009). Ash content of 15 dried market samples of Assam ranged from $9.28 \%$ to $28.72 \%$ (Vijayan and Surendran, 2012).

\section{Changes in physico-chemical parameters}

From the results, it was observed that $\mathrm{pH}$ values were lowest in salt dried Pangasius (5.01) (Table 2). The $\mathrm{pH}$ values of fish dried at $50{ }^{\circ} \mathrm{C}, 60{ }^{\circ} \mathrm{C}$ and $70{ }^{\circ} \mathrm{C}$ of kiln drying were recorded as $6.34,6.12$, and 6.33 respectively. The decrease in $\mathrm{pH}$ may be due to the fact that true lactic acid fermentation does not occur during drying. Chabbouh et al., (2011) reported a decrease in $\mathrm{pH}$ of dried salted beef samples from 5.57 to 5.40. The $\mathrm{pH}$ values of unsalted sundried Pangasius were 6.86 and that of salted sundried Pangasius was 5.01. The increase in $\mathrm{pH}$ of unsalted and sundried fish may be due to production of nitrogenous compounds during drying. Addition of salt to fish decreases the $\mathrm{pH}$ of fish due to increase in acidic compounds (Farid et al., 2014). The reduction in the $\mathrm{pH}$ of the salt washed dagaa fish was due to the leaching of the salt soluble proteins (Owaga et al., 2009).

TVBN has decreased with the increase in temperature of kiln drying with the values ranging from 28.53, 25.33 and $15.61 \mathrm{mg} \mathrm{N}$ $/ 100 \mathrm{~g}$ at temperatures of $50^{\circ} \mathrm{C}, 60^{\circ} \mathrm{C}, 70^{\circ} \mathrm{C}$ respectively (Table 2). The TVBN value of unsalted sun-dried Pangasius was $29.28 \mathrm{mg}$ $\mathrm{N} / 100 \mathrm{~g}$ and the TVBN value of salted sundried Pangasius was $19.58 \mathrm{mg} \mathrm{N} / 100 \mathrm{~g}$. According to Nooralabettu (2008) the autolytic enzyme activity in fish flesh can be reduced by addition of sodium chloride to fish.

The TVBN value was higher in the preparation of Layú a Chinese cured product when compared to other drying methods (sun drying, drying at 5,15 and $45^{\circ} \mathrm{C}$ and intermittent drying). The higher TVBN value during the preparation of Layú indicated the effect of the curing process on the increase of TVBN levels (Zhang et al., 2013). Deng et al., (2014) reported that TVBN value has increased in hot air dried squid samples. The endogenous proteases and microbial 
contamination are the main sources causing the increase in TVB-N value during the preservation and processing of fish and fish products (Lenfant et al., 2013).

Table.1 Changes in proximate composition (\%) of Pangasius hypophthalmus at Different drying conditions

\begin{tabular}{ccccc}
\hline Conditions & Moisture & Protein (N x 6.25) & Crude fat & Ash \\
\hline Fresh & $78.14 \pm 0.45^{\mathrm{e}}$ & $18.23 \pm 0.04^{\mathrm{a}}$ & $2.29 \pm 0.36^{\mathrm{a}}$ & $1.44 \pm 0.85^{\mathrm{a}}$ \\
MD $50^{\circ} \mathrm{C}$ & $16.67 \pm 0.11^{\mathrm{d}}$ & $62.77 \pm 0.31^{\mathrm{c}}$ & $15.45 \pm 0.32^{\mathrm{d}}$ & $3.63 \pm 0.04^{\mathrm{b}}$ \\
MD $60^{\circ} \mathrm{C}$ & $13.50 \pm 0.11^{\mathrm{a}}$ & $65.16 \pm 0.63^{\mathrm{e}}$ & $15.31 \pm 0.21^{\mathrm{d}}$ & $4.38 \pm 0.14^{\mathrm{c}}$ \\
MD 70 C & $14.53 \pm 0.11^{\mathrm{b}}$ & $63.98 \pm 0.34^{\mathrm{d}}$ & $14.48 \pm 0.06^{\mathrm{c}}$ & $4.88 \pm 0.11^{\mathrm{d}}$ \\
Unsalted and Sun drying & $14.59 \pm 0.18^{\mathrm{b}}$ & $63.39 \pm 0.18^{\mathrm{cd}}$ & $15.17 \pm 0.11^{\mathrm{d}}$ & $5.22 \pm 0.27^{\mathrm{d}}$ \\
Salted and sun drying & $15.36 \pm 0.38^{\mathrm{c}}$ & $55.53 \pm 0.30^{\mathrm{b}}$ & $9.32 \pm 0.35^{\mathrm{b}}$ & $18.72 \pm 0.49^{\mathrm{e}}$ \\
\hline
\end{tabular}

$*$ Each value is represented as arithmetic mean $\pm \mathrm{SD}(\mathrm{n}=3)$.

Different superscripts in the same column indicate the values are significantly different $(\mathrm{p} \leq 0.05)$, (MD-Kiln drying)

Table.2 Changes in physico-chemical parameters of Pangasius hypophthalmus at different drying conditions

\begin{tabular}{|c|c|c|c|c|c|c|}
\hline Conditions & pH & $\begin{array}{c}\text { TVBN } \\
(\mathrm{mg} \mathrm{N} / 100 \mathrm{~g})\end{array}$ & $\begin{array}{c}\mathbf{P V} \\
\text { (meq of } \mathrm{O}_{2} / \mathrm{kg} \\
\text { of fat) }\end{array}$ & $\begin{array}{c}\text { FFA } \\
(\% \text { oleic acid })\end{array}$ & $\begin{array}{c}\text { TBARS } \\
\text { (mg malonaldehyde } \\
/ \mathrm{kg})\end{array}$ & $\begin{array}{c}\text { Water } \\
\text { activity }\end{array}$ \\
\hline Fresh & $6.75 \pm 0.05^{\mathrm{e}}$ & $4.95 \pm 0.18^{\mathrm{a}}$ & $0.07 \pm 0.01^{\mathrm{a}}$ & $0.26 \pm 0.03^{\mathrm{a}}$ & $0.04 \pm 0.00^{\mathrm{a}}$ & $0.93 \pm 0.00^{\mathrm{d}}$ \\
\hline $\mathrm{MD} 50^{\circ} \mathrm{C}$ & $6.34 \pm 0.02^{c}$ & $28.53 \pm 0.40^{\mathrm{e}}$ & $2.99 \pm 0.05^{\mathrm{d}}$ & $0.66 \pm 0.04^{c}$ & $0.54 \pm 0.01^{\mathrm{d}}$ & $0.72 \pm 0.01^{\mathrm{c}}$ \\
\hline $\mathrm{MD} 60^{\circ} \mathrm{C}$ & $6.12 \pm 0.02^{b}$ & $25.33 \pm 0.20^{\mathrm{d}}$ & $2.90 \pm 0.04^{\mathrm{c}}$ & $0.52 \pm 0.00^{\mathrm{b}}$ & $0.35 \pm 0.01^{\mathrm{c}}$ & $0.74 \pm 0.01^{\mathrm{c}}$ \\
\hline $\operatorname{MD} 70^{\circ} \mathrm{C}$ & $6.33 \pm 0.02^{\mathrm{c}}$ & $15.61 \pm 0.36^{\mathrm{b}}$ & $2.50 \pm 0.28^{b}$ & $0.46 \pm 0.02^{b}$ & $0.29 \pm 0.01^{\mathrm{b}}$ & $0.72 \pm 0.01^{\mathrm{ab}}$ \\
\hline Unsalted and Sun drying & $6.86 \pm 0.04^{\mathrm{d}}$ & $29.28 \pm 0.11^{\mathrm{f}}$ & $3.89 \pm 0.02^{\mathrm{e}}$ & $1.51 \pm 0.23^{\mathrm{d}}$ & $0.56 \pm 0.01^{\mathrm{e}}$ & $0.73 \pm 0.00^{\mathrm{b}}$ \\
\hline Salted and sun drying & $5.01 \pm 0.05^{\mathrm{a}}$ & $19.58 \pm 0.43^{c}$ & $4.53 \pm 0.14^{\mathrm{f}}$ & $2.04 \pm 0.10^{\mathrm{e}}$ & $0.82 \pm 0.01^{\mathrm{f}}$ & $0.72 \pm 0.00^{\mathrm{a}}$ \\
\hline
\end{tabular}

* Each value is represented as arithmetic mean $\pm \mathrm{SD}(\mathrm{n}=3)$.

Different superscripts in the same column mean that the values are significantly different $(\mathrm{p} \leq 0.05)(\mathrm{KD}-\mathrm{Kiln}$ drying)

Table.3 Microbiological changes of Pangasius hypophthalmus at different drying conditions

\begin{tabular}{|c|c|c|c|c|}
\hline Conditions & TVC (log cfu/g) & E. coli $(\mathrm{MPN} / \mathrm{g})$ & $\begin{array}{l}\begin{array}{l}\text { Staphylococcus } \\
\text { cfu/g) }\end{array} \\
\text { spp. }\end{array}$ & $\begin{array}{l}\text { Total fungal count } \\
(\log \mathrm{cfu} / \mathrm{g})\end{array}$ \\
\hline Fresh & 4.69 & $<3.0$ & 2.55 & $<1$ \\
\hline $\mathrm{MD} 50^{\circ} \mathrm{C}$ & 3.84 & $<3.0$ & 1.04 & 1.20 \\
\hline $\mathrm{MD} 60^{\circ} \mathrm{C}$ & 3.61 & $<3.0$ & $<1$ & 1.11 \\
\hline $\mathrm{MD} 70^{\circ} \mathrm{C}$ & 2.53 & $<3.0$ & $<1$ & 1.04 \\
\hline Unsalted and Sun drying & 5.02 & 27 & 3.54 & 1.82 \\
\hline Salted and sun drying & 4.98 & $<3$ & 2.84 & 1.18 \\
\hline
\end{tabular}

* Each value is represented as arithmetic mean of 2 estimates.

$\mathrm{cfu}=$ colony forming units $; \mathrm{MPN}=$ most probable number; $\mathrm{MD}=$ Mechanical drying

Table.4 Sensory changes of Pangasius hypophthalmus at different drying conditions

\begin{tabular}{|c|c|c|c|c|c|c|}
\hline Conditions & Colour & Appearance & Odour & Taste & Texture & Overall acceptability \\
\hline Fresh & $8.52 \pm 0.19^{\mathrm{e}}$ & $8.64 \pm 0.14^{\mathrm{e}}$ & $8.60 \pm 0.07^{\mathrm{e}}$ & $8.44 \pm 0.11^{\mathrm{d}}$ & $8.65 \pm 0.70^{\mathrm{d}}$ & $8.58 \pm 0.08^{\mathrm{e}}$ \\
\hline $\mathrm{MD} 50^{\circ} \mathrm{C}$ & $7.62 \pm 0.18^{b}$ & $7.74 \pm 0.18^{b}$ & $7.62 \pm 0.16^{\mathrm{b}}$ & $7.92 \pm 0.08^{\mathrm{a}}$ & $7.54 \pm 0.11^{b}$ & $7.58 \pm 0.15^{\mathrm{b}}$ \\
\hline $\mathrm{MD} 60^{\circ} \mathrm{C}$ & $8.12 \pm 0.11^{c}$ & $8.24 \pm 0.05^{\mathrm{cd}}$ & $8.20 \pm 0.23^{\mathrm{d}}$ & $8.08 \pm 0.08^{\mathrm{ab}}$ & $8.08 \pm 0.08^{c}$ & $8.14 \pm 0.17^{\mathrm{cd}}$ \\
\hline $\operatorname{MD} 70^{\circ} \mathrm{C}$ & $8.48 \pm 0.13^{\mathrm{d}}$ & $8.41 \pm 0.06^{\mathrm{d}}$ & $8.42 \pm 0.04^{\mathrm{e}}$ & $8.08 \pm 0.08^{\mathrm{ab}}$ & $8.08 \pm 0.08^{\mathrm{c}}$ & $8.30 \pm 0.16^{\mathrm{d}}$ \\
\hline Unsalted and Sun drying & $5.4 \pm 0.812^{\mathrm{a}}$ & $4.86 \pm 0.22^{\mathrm{a}}$ & $4.58 \pm 0.16^{\mathrm{a}}$ & NA & $5.20 \pm 0.20^{\mathrm{a}}$ & $5.08 \pm 0.08^{\mathrm{a}}$ \\
\hline Salted and sun drying & $8.18 \pm 0.20^{\mathrm{c}}$ & $8.18 \pm 0.21^{\mathrm{c}}$ & $7.92 \pm 0.08^{c}$ & $8.12 \pm 0.22^{\mathrm{c}}$ & $7.12 \pm 0.13^{b}$ & $7.92 \pm 0.33^{c}$ \\
\hline
\end{tabular}

* Each value is represented as arithmetic mean $\pm \mathrm{SD}(\mathrm{n}=10)$.

Different superscripts in the same column mean that the values are significantly different $(\mathrm{p} \leq 0.05)$

MD-Mechanical drying; NA- Not analysed 
Peroxide value defines the initial stage of the oxidative changes. It was observed that the peroxide value of Pangasius decreased with the increase in temperature from 2.99 to 2.50 meq of $\mathrm{O}_{2} / \mathrm{kg}$ of fat at temperatures of 50 to $70{ }^{\circ} \mathrm{C}$ respectively (Table 2 ). The data indicated that hydrolytic and oxidative degradations have occurred during drying. High temperatures accompanying drying processes could speed up the breakdown of peroxides into their carbonyl components (Wu and Mao, 2008). This is a clear indication of the rapid decomposition of hydroperoxides into secondary oxidation products at high temperatures. Because hydroperoxides are unstable and decompose via fission, dehydration and the formation of free radicals, to form a variety of chemical products, such as alcohols, aldehydes, ketones, acids, dimers, trimers, polymers, and cyclic compounds at elevated temperatures (Fritsch, 1981; Tan et al., 2002).

According to $\mathrm{Wu}$ and Mao (2008), peroxide value was a poor indicator for heated samples while drying of grass carp fillets at hot air drying and micro wave drying. The increase in peroxide value in unsalted sun dried (3.89 meq of $\mathrm{O}_{2} / \mathrm{kg}$ of fat) and salted sun dried Pangasius (4.53 meq of $\mathrm{O}_{2} / \mathrm{kg}$ of fat) may be due the increased exposure of fish to oxygen. Prolonged exposure to light and air during initial drying has resulted in oxidation of fatty acids (Relekar et al., 2014). The Peroxide value of salted sun dried Pangasius (4.53 meq of $\mathrm{O}_{2} / \mathrm{kg}$ of fat) was highest of all drying methods. The cause of such lipid oxidation may be the pro-oxidant effect of sodium chloride (Sachithananthan, 1976). PV is not a good index of rancidity during storage of dried anchovy but TBA gave a better correlation with overall quality (Bligh et al., 1988; Inoue, 1970). PV of salt cured choodai ranged from 1.2 to $21.4 \mathrm{meq} \mathrm{O}_{2} / \mathrm{kg}$ with different salt and nitrate treatments (Pillai and Nayar, 1957). A peroxide value of 10-15 $\mathrm{meq} / \mathrm{Kg}$ of lipids indicates rancidity (Connell,
1995). The peroxide value of the mechanically dried and sundried Pangasius was within the acceptable limit indicating that the product is of good quality.

Secondary lipid oxidation compounds formed during drying were measured by the thiobarbituric acid reactive substances, (TBARS). There was an increase in the TBARS at all temperatures when compared to fresh fish (0.04 mg MDA/kg). TBARS value decreased with increase in drying temperature from $50^{\circ} \mathrm{C}(0.54 \mathrm{mg} \mathrm{MDA} / \mathrm{kg})$ to $70{ }^{\circ} \mathrm{C}(0.29$ mg MDA/kg) (Table 2), which may be due to the effect of temperature and exposure time. The formation of secondary oxidation compounds has proved to be an interesting tool to assess the chemical changes produced as a result of the drying process (Ortiz et al., 2013). Ali et al., (2011) observed an increase in TBARS value for smoked-dried and sundried flesh of two fish species (Silurus glanis and Arius parkii). Ortiz et al., (2013), reported that exposure time during drying would have a greater effect on formation of secondary lipid oxidation compounds in the dried fish samples from 40 to $60{ }^{\circ} \mathrm{C}$. In the unsalted sundried Pangasius, it was observed that TBARS value was higher $(0.56 \mathrm{mg}$ MDA/kg) than fresh sample (0.04 mg MDA/kg). According to Cakli et al., (2006), TBARS vales greater than 3-4 mg MDA/kg indicates a loss of product quality. In the present study, the TBARS values of dried Pangasius were within the limit of acceptability. Ali et al., (2011) has observed that TBARS value of sundried fish was greater than smoked dried and fresh sample in all three species (Tilapia niloticus, Silurus glanis and Arius parkii).

Free fatty acid (FFA) has increased with increase in temperature as compared with fresh Pangasius (Table 2). The FFA content of Pangasius dried in mechanical dryer at temperatures of 50,60 and $70{ }^{\circ} \mathrm{C}$ were 0.66 , 0.52 and $0.46 \%$ oleic acid respectively (Table 
2). The decrease in FFA during kiln drying at $70{ }^{\circ} \mathrm{C}$ may be due to combined effect of hot air and reduction in water activity thereby reducing hydrolysis of lipids. The FFA value of salted and unsalted dried Pangasius was 2.04 and $1.51 \%$ oleic acid respectively. Huss (1998) suggested that high level of FFA is an indication of microbial spoilage activity. The increase of FFA during drying and salt drying may be due to the extended time taken for drying during which the lipolytic enzymes may hydrolyse the lipids. Lipid hydrolysis is more rapid at high temperature and the increase of free fatty acid is an indication of microbial spoilage activity (Jeyasanta et al., 2016). Lipid hydrolysis is catalyzed by lipases which cleave fatty acids from glycerol backbone of both triglycerides and phospholipids (Hardy, 1980). Most fat acidity begins to be noticeable to the palate when the FFA value calculated as Oleic acid is about $0.5-1.5 \%$ (Pearson, 1976). From the results it was observed that mechanically dried Pangasius was within the limit but in both the sundried pangas the values were a little higher than the limit.

There was not much variation in water activity of dried Pangasius as the water activity in all dried Pangasius samples varied from 0.72 to 0.74 (Table 2). The decrease in water activity may be due to removal of water from fish during drying. According to FSSAI (2016), the $\mathrm{a}_{\mathrm{w}}$ of dried product should be less than 0.78. In the present study the values of aw were lower than 0.78 indicating that the product was stable and of good quality. Chabbouh et al., (2011) reported a decrease in water activity of salted and dried kaddid from 0.90 to 0.66 and opined that the decrease may be due to bounding of water molecules with $\mathrm{NaCl}$ and water evaporation.

\section{Microbial changes}

Among all the drying conditions, highest total viable count were observed in unsalted and sun dried Pangasius (5.02 log cfu/g) followed by salt dried Pangasius (4.98 log cfu/g) (Table 3 ). The probable reason for the decrease of TVC in salted sundried Pangasius may be due to the preservative action of salt. During the mechanical drying of Pangasius it was observed that the TVC decreased with the increase in the drying temperature from $50{ }^{\circ} \mathrm{C}$ to $70{ }^{\circ} \mathrm{C}$ with $\mathrm{TVC}$ ranging from $3.84 \mathrm{log}$ $\mathrm{cfu} / \mathrm{g}$ to $2.53 \log \mathrm{cfu} / \mathrm{g}$. An increase in total viable count (TVC) during sun drying of Scomberoides tol was observed (Patterson and Ranjitha, 2009). According to FSSAI (2017) the maximum limit of TVC in dried fish product is $5 \log (\mathrm{cfu} / \mathrm{g})$. The counts of TVC were within the limit of acceptability indicating that the product was of good quality except unsalted and sun dried Pangasius in which the TVC was recorded as $5.02 \log (\mathrm{cfu} / \mathrm{g})$ indicating the product has a chance of early spoilage. The E. coli count was higher in unsalted sun dried Pangasius (27 MPN/g) where as in other drying methods the $E$. coli content is below the determinant levels. According to FSSAI (2017), the maximum limit of $E$. coli is $20 \mathrm{MPN} / \mathrm{g}$ in dried seafood. In the present study, the counts of E. coli of mechanically dried Pangasius and salted sundried Pangasius were lower than the acceptable limit whereas the unsalted sundried Pangasius had higher E. coli counts indicating that the product was unacceptable for consumption. This increase in E. coli in the unsalted sun dried Pangasius may be due to contamination of water used for ice preparation in the market or improper hygiene of the market area. E. coli has decreased during sun drying (Patterson and Ranjitha, 2009). The decrease in the Staphylococcus spp. in all the samples dried by mechanical drying may be due to effect of temperature.

The low counts of Staphylococcus spp. also indicate that the product was prepared hygienically. The increase in Staphylococcus spp. during sun drying of salted and unsalted Pangasius may be due to the microbes, dirt 
and dust falling on the product when they are dried for 4-6 days. The total fungal counts varied with temperature from 1.20, 1.11 and $1.04 \mathrm{log} \mathrm{cfu} / \mathrm{g}$ during drying of Pangasius at temperatures of $50^{\circ} \mathrm{C}, \quad 60^{\circ} \mathrm{C}$ and $70^{\circ} \mathrm{C}$ respectively. The total fungal count of unsalted sundried Pangasius was $1.82 \mathrm{log}$ cfu/g and that of salted and sundried Pangasius was $1.18 \mathrm{log} \mathrm{cfu} / \mathrm{g}$ (Table 4). According to FSSAI (2017), the maximum limit of moulds in dried fishery products is $500 \mathrm{cfu} / \mathrm{g}(2.7 \log \mathrm{cfu} / \mathrm{g})$. In the present study it was observed that Pangasius dried in different conditions had fungal counts lower than 500cfu/g (2.7 log cfu/g).

\section{Sensory changes}

The sensory scores of Pangasius dried at different temperatures are given in table 4 . The overall sensory scores of Pangasius had shown a significant difference. Highest overall scores were observed for mechanically dried Pangasius at $70{ }^{\circ} \mathrm{C}(8.30)$ but lower overall sensory scores were observed for unsalted sundried Pangasius (5.08). Among the sensory parameters like appearance, color, odor, texture and overall acceptability were lowest for unsalted sun dried Pangasius but the texture of salted sun dried Pangasius was lower than unsalted sun dried Pangasius. In salt drying, the salt penetration is accompanied by the removal of moisture and as the salt content increases there are chances of crust formation making moisture removal difficult. Crust formation was formed on the surface of fish due to combined effect of heat and salt at $50{ }^{\circ} \mathrm{C}$ in lightly salted sardine (Bellagha et al., 2002). From the above results it was observed that the sensory scores of mechanically dried Pangasius were high at all the three temperatures indicating the high acceptance of mechanically dried Pangasius due its good colour, fishy odour and texture. Among the different temperature of mechanical drying, Pangasius dried at $70^{\circ} \mathrm{C}$ had high scores indicating high acceptance than other dried products. The unsalted sundried Pangasius had lower scores near to the rejection point indicating that the product was not acceptable which may be due to the off odour and the fish was spoiled by maggots and some remains of maggots were found after drying making the fish unacceptable. The higher sensory scores of salted sundried Pangasius might be due to the good texture, flavor and taste indicating that salted sundried Pangasius was highly acceptable. Among salted and unsalted sundried pangas, salted sundried Pangasius was more acceptable. Based on the sensory scores, mechanically dried and salted sundried Pangasius was acceptable among the different drying conditions.

From the results of the present investigation, the quality of Pangasius dried at 50, 60 and $70^{\circ} \mathrm{C}$ was superior to sun drying and salt drying and the products were produced hygienically. Among the sun drying and salt drying of Pangasius, the quality of salt dried Pangasius was superior. Though the quality of kiln dried Pangasius is more acceptable than sun dried and salt dried Pangasius, the cost involved in their production and other difficulties in using kiln drier makes it unfavorable for using by village farmers and fishermen in India. Hence salt drying which takes less time to dry and produces a good quality product can be used as an effective method of preservation for marketable size Pangasius.

\section{Acknowledgements}

The first author is thankful to Indian Council of Agricultural Research (ICAR) and Director, ICAR-Central Institute of Fisheries Education, Mumbai for providing necessary facilities for conducting this study. The first author also remains grateful to University Grants Commission (UGC) for providing 
financial assistance in the form of fellowship (RGNF).

\section{References}

Ali, A., Ahmadou, D., Mohamadou, B., Saidou, C. and Tenin, D., 2011. Influence of traditional drying and smoke-drying on the quality of three fish species (Tilapia nilotica, Silurus glanis and Arius parkii) from Lagdo Lake, Cameroon. J. Anim. Vet. Adv., 10(3), 301-306.

AOAC, 2000. Official Methods of Analysis, $18^{\text {th }}$ Edition Association of Official Analytical Chemists, Maryland, U.S.A,

APHA, 2001. Compendium of Methods for the Microbiological Examination of Foods. American Public Health Association, New York.

Begum, M., Begum, M., uddin Ahmed, S.U., Akter, T. 2013. Studies on the effectiveness of Tejpata (Cinnamomum tamala Nee) leaf extract on dried kachki (Corica soborna) fish preservation in laboratory condition. Am. J. Food Sci. Technol. 1(3), 14-17.

Bellagha, S., Amami, E., Farhat, A., Kechaou, N. 2002. Drying kinetics and characteristic drying curve of lightly salted sardine (Sardinella aurita). Drying Technol. 20(7), 1527-1538.

Bligh, E.G., Shaw, S.J., Woyewoda, A.D. 1988. Effects of drying and smoking on lipids of fish. In: Fish smoking and drying - The effect of smoking and drying on the nutritional properties of fish. Burt J.R. [Ed.] Elsevier Science Publishers, Ltd, Essex, England, 41-52

Cakli, S., Kilinc, B., Dincer, T. and Tolasa, S., 2006. Comparison of the shelf lifes of map and vacuum packaged hot smoked rainbow trout (Onchoryncus mykiss). Eur. Food Res. Technol., 224(1):19-26.

Chabbouh, M., Hajji, W., Hadj Ahmed, S.B., Farhat, A., Bellagha, S., Sahli, A. 2011. Combined effects of osmotic dehydration and convective air drying on Kaddid meats: Kinetics and quality. Drying Technol. 29(13), 1571-1579.

Chukwu, O., 2009. Influences of drying methods on nutritional properties of tilapia fish
(Oreochromis nilotieus). World J. Agr. Sci. 5(2), 256-258.

Chukwu, O., and Shaba, I.M. 2009. Effects of Drying Methods on Proximate Compositions of Catfish (Clarias gariepinus). World J. Agr. Sci. 5(1), 114116.

Clucas, I.J. and Ward, A.R. 1996. Post-harvest fisheries development: a guide to handling, preservation, processing and quality. Natural Resources Institute (NRI).

Collignan, A., Santchurn, S., Zakhia-Rozis, N. 2008, Dehydration of Muscle Foods. In Food Drying Science and Technology: Microbiology, Chemistry, Applications, Hui, Y.H., Clary, C., Farid, M.M., Faina, O.O., Noomhorm, A., Welti-Chanes, J. [Eds] Lancaster: DEStech Publications, 721-743.

Connell, J. J., 1995. Control of Fish Quality (4th Ed.). Oxford: Fishing News Books.

Darvishi, H., Farhang, A., Hazbavi, E. 2012. Mathematical Modeling of Thin-Layer Drying of Shrimp. Global J. Sci. Front. Res. 12(3), 82-90.

Deng, Y., Luo, Y., Wang, Y., Yue, J., Liu, Z., Zhong, Y., Zhao, Y., Yang, H. 2014. Drying-induced protein and microstructure damages of squid fillets affected moisture distribution and rehydration ability during rehydration. J. Food Eng. 123, 23-31.

Farid, F.B., Latifa, G.A., Nahid, M.N. and Begum, M., 2014. Effect of sun-drying on proximate composition and $\mathrm{pH}$ of shoal fish (C. striatus; Bloch, 1801) treated with salt and salt-turmeric storage at room temperature $\left(27{ }^{\circ} \mathrm{C}-30{ }^{\circ} \mathrm{C}\right)$. J. Anim. Vet. Sci., 7(9), 01-08.

Fritsch, C.W., 1981. Measurements of frying fat deterioration: a brief review. J. Am. Oil Chem. Soc., 58(3), 272-274.

FSSAI, 2016. Food Safety and Standards (Food Products Standards and Food Additives) Amendment Regulations, 2016 related to standards of salted fish/dried salted fish. Dt: 11.01.2016, Food Safety and Standards Authority of India, New Delhi.

FSSAI, 2017. Final Gazette Notification of Food Safety and Standards (Food Product Standards and Food Additives) Third Amendment Regulation, 2017 related to 
microbiological standards for fish and fish products. Dt: 13.02.2017, Food Safety and Standards Authority of India, New Delhi.

Guan, Z., Wang, X., Li, M., Jiang, X. 2013. Mathematical modeling on hot air drying of thin layer fresh tilapia fillets. Pol. J. Food Nutr. Sci. 63(1), 25-33.

Hardy, R., 1980. Fish lipids, Part 2. In Advances in Fish Science and Technology. Connell, J.J.; [Ed.], Surrey, Fishing News Books Ltd, 103-111

Huss, H. M., 1988. Fresh fish quality and quality changes. FAO/DANIDA Training Programme on Fish Technology and Quality Control. FAO Fisheries Series. 29, pp. 132.

Immaculate, J., Sinduja, P., Jamila, P. 2012. Biochemical and microbial qualities of Sardinella fimbriata sun dried in different methods. Int Food Res J. 19(4), 1699-703.

Inoue, T., 1970. Oxidation of oil contained in dried anchovy during storage. Bull. Fac. Edu. Kanazawa University, 2, 61-67.

Jacob, M.B., 1958. The Chemical Analysis of Foods and Food Products. Kreiger Publishing Co. Inc. New York, USA. 393394.

Jain, D., and Pathare, P. B. 2007. Study the drying kinetics of open sun drying of fish. J. Food Eng. 78(4), 1315-1319.

Jeyasanta, I.K., Sinduja, P., Jamila, P. 2016. Wet and Dry Salting Processing of Double Spotted Queen Fish Scomberoides Lysan (Forsskål, 1775). Int. J. Fish. Aquat. Stud. 4(3), 330-38.

Lenfant, F., Hartmann, C., Watzke, B., Breton, O., Loret, C., Martin, N. 2013. Impact of the shape on sensory properties of individual dark chocolate pieces. LWT-Food Sci. Technol. 51(2), 545-552.

Mustapha, M. K., Ajibola, T. B., Salako, A. F., \& Ademola, S. K. 2014. Solar drying and organoleptic characteristics of two tropical African fish species using improved low- cost solar driers. Food Sci. Nutr. 2(3), 244-250.

Ninawe, A. S., and Rathnakumar, K. 2008. Preservation of Fish by Curing. In Fish Processing Technology and Product Development, New Delhi: Narendra Publishing House,, 112-147.
Nooralabettu, K.P., 2008. Effect of sun drying and artificial drying of fresh, salted Bombay duck (Harpodon neherius) on the physical characteristics of the product. J. Aquat. Food Prod. Technol., 17(2), 99-116.

Ojutiku, R.O., Kolo, R.J., Mohammed, M.L. 2009. Comparative study of sun drying and solar tent drying of Hyperopisus bebe occidentalis. Pak. J. Nutr. 8(7), 955-957.

Ortiz, J., Lemus-Mondaca, R., Vega-Gálvez, A., Ah-Hen, K., Puente-Diaz, L., Zura-Bravo, L., Aubourg, S. 2013. Influence of airdrying temperature on drying kinetics, colour, firmness and biochemical characteristics of Atlantic salmon (Salmo salar L.) fillets. Food Chem. 139(1), 162169.

Owaga, E.E., Onyango, C.A., Njoroge, C.K. 2009. Effects of selected washing treatments and drying temperatures on biochemical and microbiological quality of dagaa (Rastrineobola argentea). Afr. J. Food Agric. Nutr. Dev. 9(3), 830-845.

Patterson, J., and Ranjitha, G. 2009. Qualities of commercially and experimentally sun dried fin fish, Scomberoides tol. Afr. J. Food Sci. 3(10), 299-302.

Pearson, D., 1976. The Chemical Analysis of Foods. $7^{\text {th }}$ edition, Churchill, Livingstone, Edinburgh, London and New York.

Pillai, V.K., and Nayar, M.R. 1957. Determination of total volatile nitrogen in cured fish products. Indian J. Fish., 4(2), 295-303.

Rahman, M.S., 2006. Drying of Fish and Seafood. In: Mujumdar, A.S. (Ed.), Handbook of Industrial Drying. CRC Press, USA, 547559.

Relekar, S.S., Joshi, S.A., Gore, S.B. and Kulkarni, A.K., 2014. Effect of improved drying methods on biochemical and microbiological quality of dried small head ribbon fish, Lepturacanthus savala. Int. J. Fish. Aquat. Stud., 1(5), 60-66.

Sachithananthan, K., 1976. Dried fish production in Sri Lanka. JJ2 "Conference Proceedings Handling. Processing and Marketing of Tropical Fish. Tropical Products Institute, London (pp. 323-325).

Sarower-E-Mahfuj, M., Hossain, M. B., and Minar, M. H. 2012. Biochemical Composition of an Endangered Fish, Labeo 
bata (Hamilton, 1822) from Bangladesh Waters. Am. J. Food Technol. 7(10), 633641.

Selmi, S., Bouriga, N., Cherif, M., Toujani, M., Trabelsi, M. 2010. Effects of drying process on biochemical and microbiological quality of silverside (fish) Atherina lagunae. Int. J. Food Sci. Tech. 45(6), 1161-1168.

SPSS, 2010. SPSS for windows. Release 16. Chicago, 1: SPSS Inc.

Taiwo, K.A., Eshtiaghi, M.N., Ade- Omowaye, B.I., Knorr, D. 2003. Osmotic dehydration of strawberry halves: influence of osmotic agents and pretreatment methods on mass transfer and product characteristics. Int $\mathrm{J}$ Food Sci Tech. 38(6), 693-707.

Tan, C.P., Man, Y.C., Jinap, S. and Yusoff, M.S.A., 2002. Effects of microwave heating on the quality characteristics and thermal properties of RBD palm olein. Innov. Food Sci. Emerg. Technol., 3(2), 157-163.

Tarladgis, B.G., Watts, B.M., Younathan, M.T., Dugan, Jr. L. 1960. A distillation method for the quantitative determination of malondialdehyde in rancid foods. J. Am. Oil Chem. Soc. 37(1), 44-48.

Valdimarsson, G., and Guđ̋jö Urnsd' Attir, B. 1984. The microbiology of stockfish during the drying process. J. Appl. Bacteriol.
57(3), 413-421.

Valencia-Pérez, A.Z., García-Morales, M.H., Cárdenas-López, J.L., Herrera-Urbina, J.R., Rouzaud-Sández, O., Ezquerra-Brauer, J.M. 2008. Effect of thermal process on connective tissue from jumbo squid (Dosidicus gigas) mantle. Food Chem. 107(4), 1371-1378.

Vega-Gálvez, A., Andrés, A., Gonzalez, E., Notte-Cuello, E., Chacana, M., LemusMondaca, R. 2009. Mathematical modelling on the drying process of yellow squat lobster (Cervimunida jhoni) fishery waste for animal feed. Anim. Feed Sci. Tech. 151(3), 268-279.

Vijayan, P.K., and Surendran, P.K., 2012. Quality aspects of dried fish marketed in the north eastern states of India. Fish. Technol., $49,167-171$.

Vyncke, W., 1996. Comparison of the official EC method for the determination of total volatile bases in fish with routine methods. Arch. Lebensmittelhyg., 47, 110111.

Zhang, J., Fang, Z.; Cao, Y.; Xu, Y.; Hu, Y.; Ye, X.; Yang, W. 2013. Effect of different drying processes on the protein degradation and sensory quality of layú: A Chinese drycuring grass carp. Dry. Technol., 31(13-14), $1715-22$.

\section{How to cite this article:}

Gonugodugu Praveen Kumar, K.A. Martin Xavier, Binaya Bhusan Nayak, H. Sanath Kumar, Gudipati Venkateshwarlu and Amjad K. Balange. 2017. Effect of Different Drying Methods on the Quality Characteristics of Pangasius hypophthalmus. Int.J.Curr.Microbiol.App.Sci. 6(10): 184-195. doi: https://doi.org/10.20546/ijcmas.2017.610.024 